WYBRANE ZAGADNIENIA ANALIZY USZKODZEŃ WIELKOPOWIESZCHNIOWYCH OBIEKTÓW BUDOWLANYCH

\title{
ОКРЕМІ ПИТАННЯ АНАЛІЗУ УШКОДЖЕНЬ БУДІВЕЛЬНИХ ОБ'ЄКТІВ ВЕЛИКОЇ ПЛОЩІ
}

\section{SELECTED ISSUES OF THE ANALYSIS OF LARGE AREA CIVIL ENGINEERING STRUCTURES}

Marek Dohojda dr inż., adiunkt, orcid.org/0000-0003-0382-805X, Joanna Witkowska - Dobrev dr inż., asystent, orcid.org/0000-0001-6613-5037.

(Szkoła Główna Gospodarstwa Wiejskiego, Warszawa)

Марек Дохойда, orcid.org/0000-0003-0382-805Х, Йоанна Вітковска-Добрев orcid.org/0000-0001-6613-5037(Варшавський університет природничих наук)

Marek Dohojda Ph.D., assistant professor orcid.org/0000-0003-0382-805X, Joanna Witkowska - Dobrev Ph.D., assistant 0000-0001-6613-5037 (Warsaw University of Life Sciences - SGGW)

W pracy została przedstawiona tematyka problemów towarzyszących wielkopowierzchniowym obiektom budowlanym do których zaliczamy garaże podziemne. Dokonano analizy technicznej wybranych problemów ujawniających się w garażach w okresie ich eksploatacji. Projektowanie, a następnie realizacja obiektów spełniających funkcję garaży podziemnych najczęściej jest związane ze skomplikowanymi zagadnieniami inżynierskimi. Do najczęstszych występujących usterek konstrukcyjnych $w$ garażach podziemnych można zaliczyć: pęknięcia płyty dennej, zarysowania stropów pośrednich, niewłaściwego oszacowania skurczu betonu, brak dylatacji czy też błędnie przyjęte warunki gruntowo-wodne.

У роботі представлений перелік проблем, що супроводжують будівельні об'єкти великої площі, в тому числі й підземні гаражі. Здійснено технічний аналіз окремих проблем, що виникають в таких будівлях під час їх експлуатації. Проектування, а пізніше і будівництво підземних гаражів найчастіше, пов'язане 3 вирішеням складних інженерних питань. Згідно з ними до найпоширеніших конструкційних недоліків у підземних гаражах віднесні: тріщини нижньої плити, порушення поверхових перекриттів, невластиве кручення бетону, відсутність дилатації або також помилково прийняті грунтово-водні умови. 
The paper concerns complex engineering challenges associated with multistorey underground car parks. An analysis of selected issues in underground garages during the exploitation was performed. The design and implementation of structures of which function are underground garages is most often associated with serious engineering challenges. For structural reasons frequently occurring faults in garages may include fracture of the bottom slab and intermediate floors resulting from improper design of reinforcement, concrete shrinkage, lack of expansion joints or incorrectly adopted soil-water conditions.

Słowa kluczowe: podziemny garaż wielostanowiskowy, błędy projektowe, błędywykonawcze

підземний багатомісний гараж, проектні помилки, будівельні помилки multi-underground garages, design and implementation errors

Parkowanie samochodów osobowych w dużych aglomeracjach miejskich nastręcza duże trudności logistyczne i techniczne Liczba indywidualnych środków transportu stale wzrasta, powodując konieczność zwiększenia ilości miejsc postojowych.

Znalezienie wolnych terenów pod budowę parkingów w miastach jest praktycznie niemożliwe, a często również zbyt kosztowne. Racjonalnym rozwiązaniem tego problemu są wielostanowiskowe parkingi podziemne fot.1. Pomimo zwiększonych kosztów, budowanie garaży podziemnych w obiektach mieszkalnych i biurowych staje się standardem. Biorąc od uwagę specyfikę użytkowania garaży podziemnych musi zostać spełniony warunek bezpieczeństwa użytkowania, który obejmuje użytkowników jak i pozostawione pojazdy [8]. Ponadto należy wziąć pod uwagę warunek i funkcjonalności i przejrzystości wewnętrznego układu komunikacyjnego oraz estetyki wnętrz budynku. Niestety na wielu obiektach $\mathrm{z}$ powodu nieprawidłowości projektowych i niedbałego wykonawstwa powstaje wiele usterek, które utrudniają użytkowanie i generują duże koszty eksploatacji i napraw. Nowe inwestycje są realizowane najczęściej w zwartej zabudowie, a kryterium wyboru wykonawcy i zastosowanych materiałów stanowi najniższa cena. Dla projektantów spełnienie obowiązujących wymagań wynikających $\mathrm{z}$ norm i przepisów prawa nie jest bardzo trudne, niestety jakość projektu (często pozbawiona istotnych detali) i przyjęcie nieodpowiednich rozwiązań materiałowych skutkuje powstawaniem wad i usterek $[5,6]$.

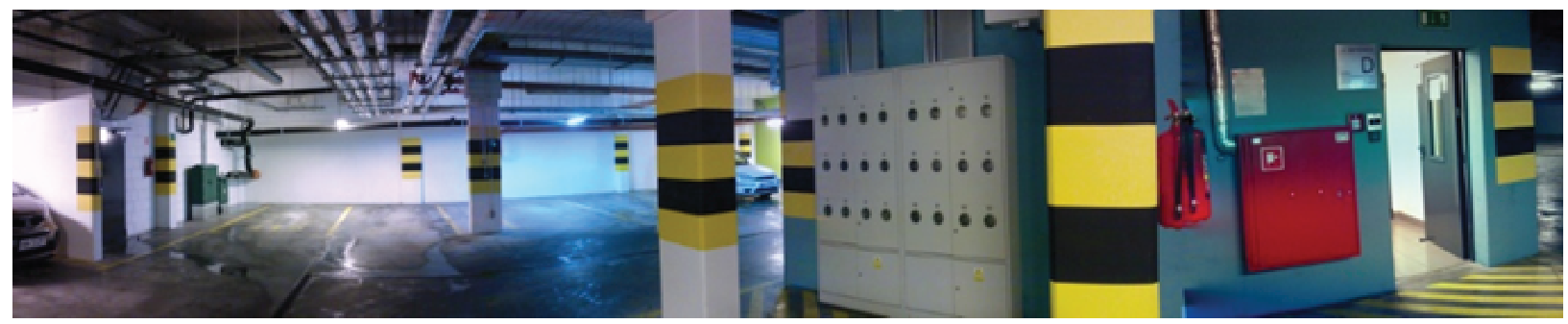

Fotografia 1. Garaż podziemny w budynku wielorodzinnym - Warszawa -Targówek

(fot. Julia Moczydłowska) 


\section{Wymagania prawne}

Garaże podziemne jako budynki i budowle powinny spełniać określone prawem wymagania techniczne (Rozporządzenie Ministra Infrastruktury z dnia 12 kwietnia 2002r. W sprawie warunków technicznych, jakim powinny odpowiadać budynki i ich usytuowanie (Dz. U. $2002 \mathrm{nr} 75$ poz. 690, z późn. zm.) [11], „Garaże do przechowywania i bieżącej, niezawodowej obsługi samochodów osobowych, stanowiący samodzielny obiekt budowlany lub część innego obiektu, będący garażem zamkniętym $\mathrm{z}$ pełną obudową zewnętrzną i zamykanymi otworami, bądź garażem otwartym bez ścian zewnętrznych albo ze ścianami niepełnymi lub ażurowymi, powinien być mieć [...]:

1. Wysokość w świetle konstrukcji co najmniej 2,2 $\mathrm{m}$ i do spodu przewodów i urządzeń instalacyjnych $2 \mathrm{~m}$,

2. Wjazdy lub wrota garażowe co najmniej o szerokości $2,3 \mathrm{~m}$ i wysokości $2 \mathrm{~m} \mathrm{w}$ świetle, elektryczną instalację oświetleniową,

3. Zapewnioną wymianę powietrza, zgodnie z $§ 108$,

4. Wpusty podłogowe $\mathrm{z}$ syfonem $\mathrm{i}$ osadnikami $\mathrm{w}$ garażu $\mathrm{z}$ instalacją wodociągową lub przeciwpożarową tryskaczową, w garażu podziemnym przed wjazdem do niego oraz w garażu nadziemnym o pojemności powyżej 25 samochodów,

\section{Instalację przeciwpożarową, wymaganą przepisami dotyczącymi ochrony} przeciwpożarowej, zabezpieczoną przed zamarzaniem".

Konstrukcja garażu podziemnego musi być, tak zaprojektowana i wykonana, aby oddziaływania przekazywane na obiekt nie powodowały przekroczenia nośności, a eksploatacja obiektu nie stanowiła zagrożenia dla użytkowników. Wymaganiem wynikającym z PN-EN 1990 „Podstawy projektowania konstrukcji” jest przede wszystkim zapewnienie niezawodności obiektu [12].

Spełnienie powyższych wymagań jest warunkiem trwałości garażu podziemnego, gdzie najczęściej panują warunki odpowiadające klasie ekspozycji XC3 i XD3 według PN-EN 206:2014-04 „Beton- Wymagania, właściwości, produkcja i zgodność”[13]. W Eurokodzie2 PN-EN 1992-1-1 „Projektowanie konstrukcji z betonu'[14], ujęto zagadnienia projektowania konstrukcji przy założeniach różnych modeli wraz z zachowaniem progu ekonomicznego. Jak już wspomniano wymaganiem podstawowym, jakie powinna spełniać konstrukcja jest jego niezawodność. Obiekt należy zaprojektować tak, aby w zakładanym okresie jego użytkowania, $\mathrm{z}$ odpowiednim stopniem niezawodności, $\mathrm{w}$ wyniku działających na niego oddziaływań środowiska, nie zostały przekroczone stany graniczne nośnosci i użytkowalnosci.

\section{Analiza wybranych błędów projektowo-wykonawczych}

Analizie poddano wybrane, najczęstsze błędy, które pojawiają się w obiektach wielostanowiskowych. Błędy te można podzielić na następujące trzy grupy (Francke, 2010) [4]:

Pierwsza grupa obejmuje błędy projektowo-wykonawcze, które są spowodowane zastosowaniem niewłaściwych materiałów (wyrobów) lub 
rozwiązań w poszczególnych warstwach przekroju np. płyty stropowej nad garażem.

W szczególności dotyczy to miejsc konstrukcyjnych, w których nastąpił nieprawidłowy układ warstw wynikający z błędnego projektu lub wykonawstwa.

- Druga grupa obejmuje błędy wykonawcze i nadzoru, spowodowane nieprawidłowym przygotowaniem i wykonaniem robót, a także nieodpowiednią pielęgnacją betonu przy wykonywaniu prac.

- Trzecia grupa to błędy nadzoru wykonawczo-inwestorskiego. Należy, przez to rozumieć brak odbioru robót zanikających lub nieprawidłowy odbiór wykonanych prac. Najczęściej występujące nieprawidłowości w obiektach typu podziemnych wielostanowiskowych garaży to np. nieszczelność ścian zewnętrznych na których są widoczne przesiąki wody (np. fot.3,4,5), [7].

Uszkodzenia budynku sąsiadującego z nowo realizowanym jednokondygnacyjnym garażem podziemnym, wywołane drganiami na skutek metody udarowej przy wykonaniu ścianki szczelinowej.

Drgania te wraz z dynamicznymi oddziaływaniami związanymi z ruchem ulicznym odbywającym się przy inwestycji i graniczącą $\mathrm{z}$ nią budynkami powodują powiększenie istniejących rys oraz powstanie nowych, a także powstanie pęknięć konstrukcji ścian i stropów (fot.2) [9].

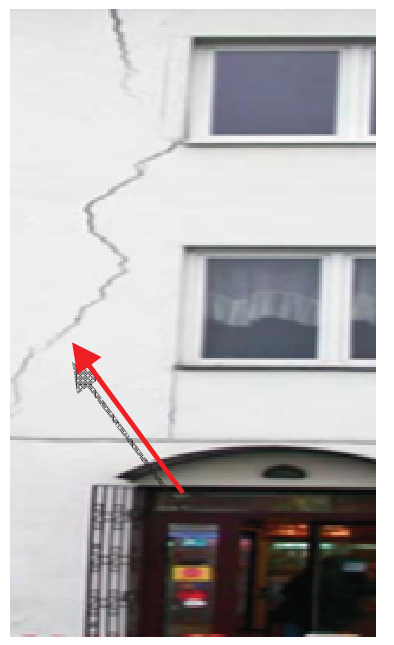

Fotografia 2. Uszkodzenia budynku sąsiadującego z nowo realizowanym jednokondygnacyjnym garażem podziemnym [8].

Drgania te wraz z dynamicznymi oddziaływaniami związanymi z ruchem ulicznym odbywającym się przy inwestycji i graniczące $\mathrm{z}$ nią budynkami powodują powiększenie istniejących rys oraz powstanie nowych, a także powstanie pęknięć konstrukcji ścian i stropów (fot. 2) [9].

Projektując tego typu obiekty, należy brać pod uwagę tolerancje wykonania poszczególnych elementów konstrukcyjnych. W projektowaniu obudowy garaż, powinno się uwzględnić tolerancje wymiarów, w tym: odchylenia od pionu powierzchni ścian szczelinowych, lokalne wybrzuszenia jej powierzchni, przesunięcia w pionie wnęk $\mathrm{w}$ miejscu podparcia stropów kondygnacji podziemnych. Poza wymienionymi odchyłkami gabarytów, wynikającymi z 
prawidłowej technologii wykonania, mogą również powstać odchyłki spowodowane usterkami realizacyjnymi. Takie usterki można sklasyfikować jako usuwalne $i$ trwałe (nieusuwalne). Usterki usuwalne zazwyczaj łatwo wyeliminować, stosując różnego rodzaju środki naprawcze, np. przecieki przez szczeliny dylatacyjne bądź robocze mogą być naprawiane odpowiednimi środkami iniekcyjnymi (fot. 3a i b). Usterki nieusuwalne, jak np. większe odchylenie ściany szczelinowej od pionu niż wynikające $\mathrm{z}$ zakładanej tolerancji wykonania, mogą być przyczyną zmniejszenia gabarytów stanowisk postojowych, dróg manewrowych bądź pochylni wjazdowo-zjazdowych. W sytuacji nieuwzględnienia możliwości wystąpienia tego rodzaju usterek w rozwiązaniu projektowym, mogą wystąpić ograniczenia w sposobie użytkowania garażu i czasem znaczące utrudnienia w tym zakresie [8].
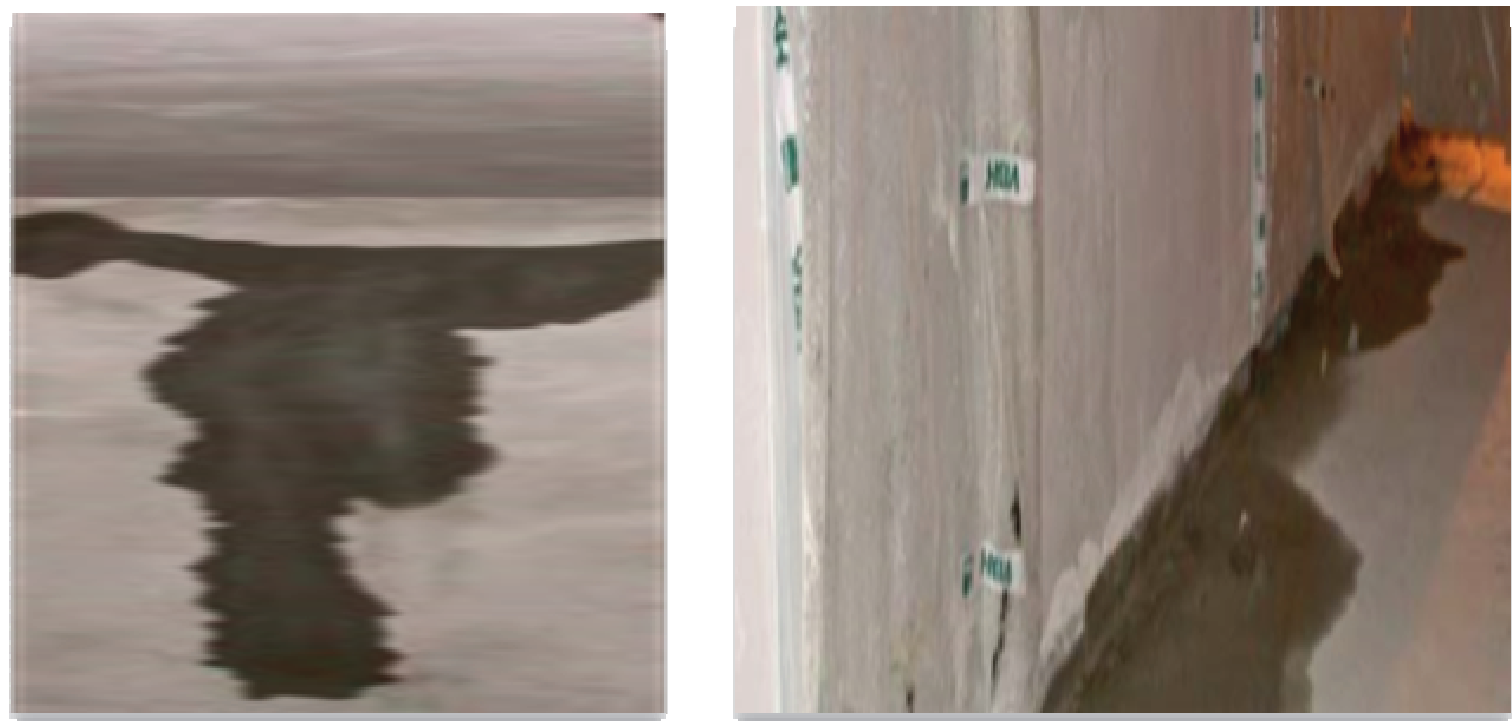

Fotografia 3. Przykłady usterek wykonawczych ścian szczelinowych: a) przecieki przez ścianę szczelinową, b) przecieki przez strop w styku ze ścianami szczelinowymi [8].

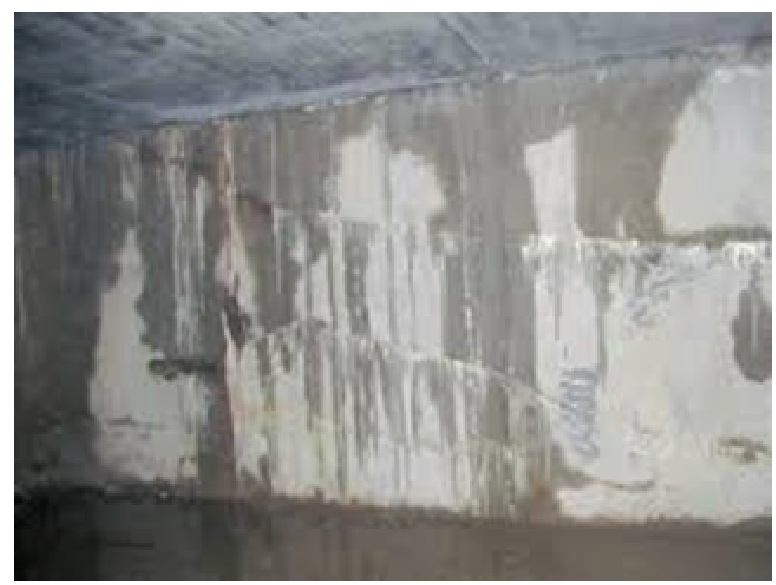

Fotografia 4. Zainiektowane rysy w ścianie oraz częsty widok pozornych Przecieków wody opadowej pochodzącej z wyższych kondygnacji [8]. 

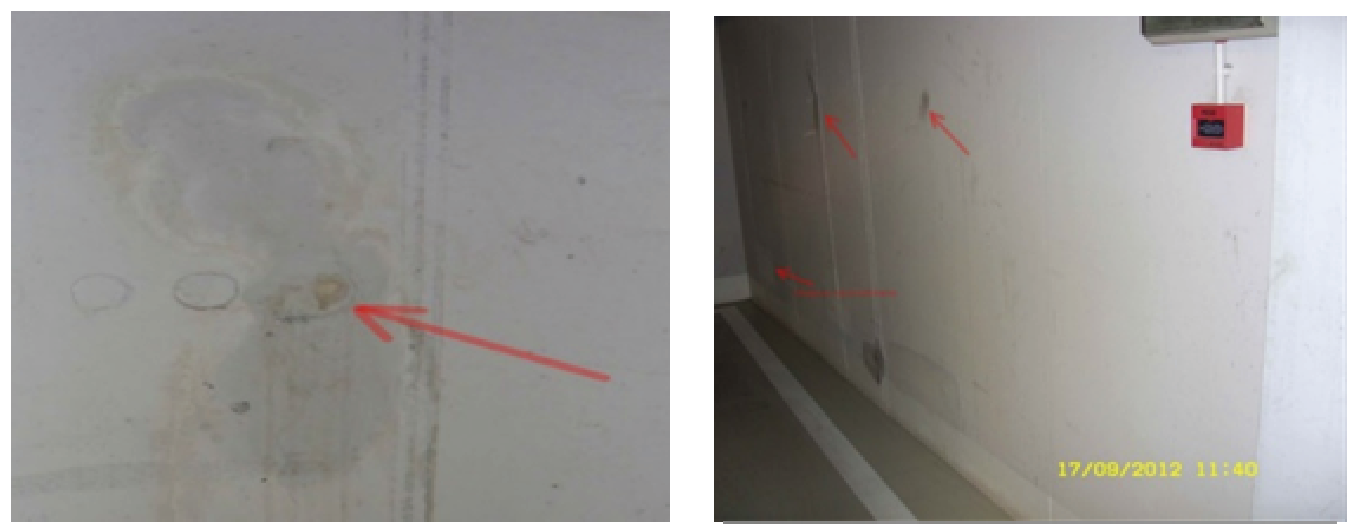

Fotografia. 5 a, b. Zawilgocenia na ścianach zewnętrznych garażu.

Zawilgocenie ścian zewnętrznych garażu jest skutkiem nieszczelność izolacji pionowej. Woda może także przenikać przez ścianę $\mathrm{w}$ miejscach występujących pęknięć oraz niedoszczelnionych otworów po łącznikach szalunku. Usunięcie wspomnianych nieszczelności może nastąpić po przez wykonanie ciśnieniowej iniekcji odpowiednimi żywicami., (fot 4 i 5). Kolejny pojawiający się problem to nieszczelność dylatacji, powodująca przeciek wody (fot. 6), [10].

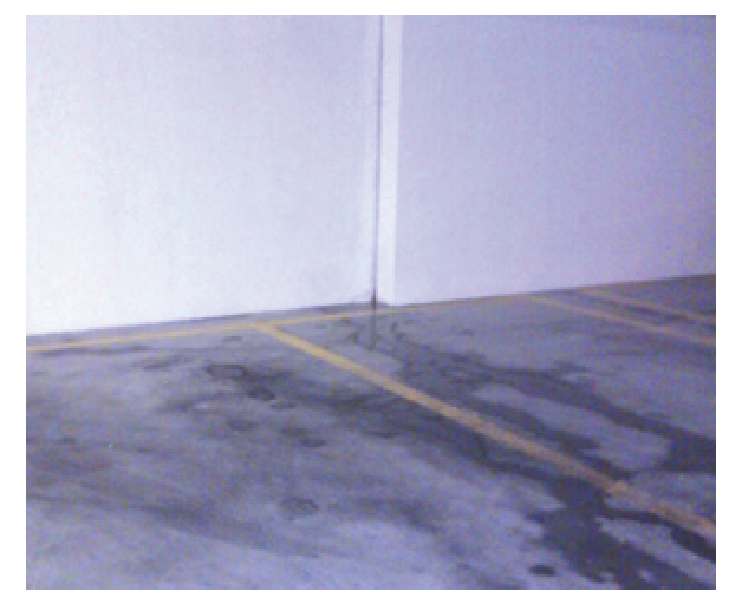

Fotografia. 6. Przeciek z dylatacji konstrukcyjnej.

Z dużym prawdopodobieństwem można założyć, że przyczyną tego stanu była niewystarczająco zabezpieczona podczas betonowania zastosowana taśmą dylatacyjna. Przeciek powierzchniowy dylatacji jest łatwy do zlokalizowania. Często występuje również wzdłuż styku taśm dylatacyjnych $\mathrm{z}$ betonem lub też $\mathrm{w}$ miejscu łączenia taśm. Proces naprawczy uszczelnienia dylatacji od strony naporu wody (przeciek poniżej poziomu terenu), polega na uszczelnieniu dylatacji w obszarze montażu taśmy żywicami poliuretanowymi lub masami peczniejacymi. Ze względu na trudne do zlokalizowania źródło przecieku, uszczelnienie powinno być wykonane wzdłuż całej dylatacji. Rozwiązaniem może także okazać się zamocowanie systemowego profilu uszczelniającego mocowanego mechanicznie do podłoża ściany lub płyty.

Kolejnym problemem, który pojawia się w omawianych obiektach to nieszczelne odwodnienie liniowe garażu. Oznacza to pojawiającą się wodę w garażu, która nie jest w wystarczający sposób odprowadzana za pomocą liniowego odwodnienia, wynika to $\mathrm{z}$ faktu, że koryta nie są wystarczająco oddylatowane od posadzki betonowej lub są nieszczelne. Obserwowane są często widoczne wykwity soli i zawilgocenia $\mathrm{w}$ miejscu styku koryt i posadzki. Pojawia się również korozja rusztu (Fot. 7) i koryt w przypadku koryt metalowych oraz woda pod samym korytem. 


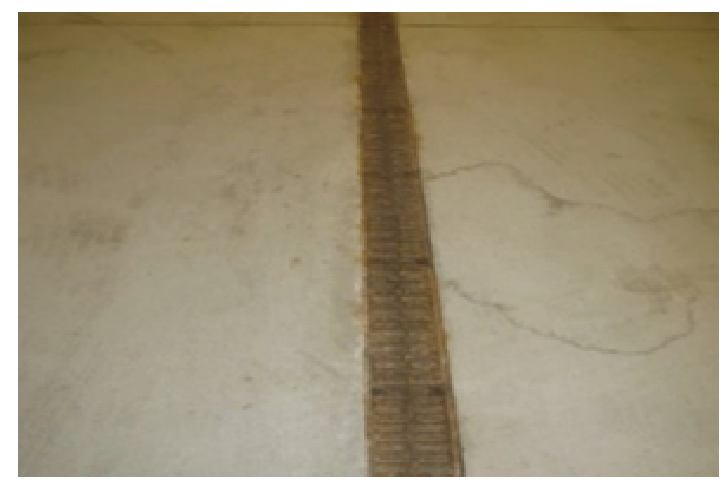

Fotografia. 7. Widoczne ślady korozji wskutek zalegania wody w korycie

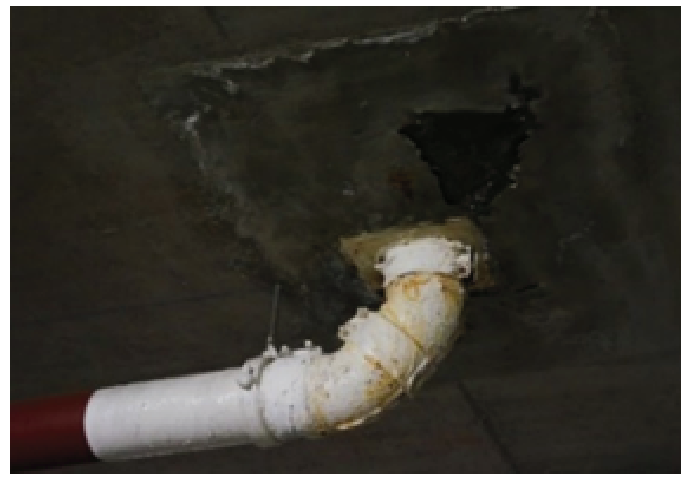

Fotografia.8. Wykwity przy przejściu rury przez strop pośredni w garażu wielopoziomowym

Pociąga to za sobą uszkodzenie koryta, co skutkuje widocznymi i licznymi spękaniami oraz ubytkami profilu koryta, finalnie powoduje to brak stabilnego posadowienia. W wyniku toczenia się kół pojazdów po posadzce, która jest niewłaściwie oddylatowana od koryt, następuje zmiana ich warunków posadowienia. Przejścia instalacji wodno-kanalizacyjnej przez strop pośredni stanowią kolejne miejsca newralgiczne i dlatego mogą pojawiać się tam też widoczne zacieki oraz degradacja betonu przy przejściu rury kanalizacyjnej przez strop pośredni, (fot. 8). Pojawienie się opisanych na (fot. 9) uszkodzeń jest skutkiem niewykonania izolacji przejścia instalacji przez strop oraz braku systemowego kołnierza uszczelniającego. W przypadku takich usterek zalecenia się doszczelnienie przejścia przy użyciu specjalnego sznura uszczelniającego oraz elastycznego kitu uszczelniającego. Należy również, wokół przejść wykonać obwodowo iniekcję żywicą poliuretanową lub należy wykuć cały spust i wykonać go od początku właściwie[2,4].

Kolejny rodzaj wad wykonawczych stanowią nieszczelne stropy pośrednie. Taki stan rzeczy, jest skutkiem błędnych założeń przy projektowaniu, że garaż to pomieszczenie suche. Wynikiem tego jest brak na stropie pośrednim izolacji przeciwwodnej. Skutkiem braku takiej izolacji są przecieki przez zarysowania stropów oraz wszelkie niedoszczelnione elementy (dylatacje konstrukcyjne i przejścia instalacji). Zaleca się uszczelnienie wszystkich rys i pęknięć. Rysy o rozwartości powyżej $0,5 \mathrm{~mm}$ uszczelnia się metodą iniekcji grawitacyjnej, a rysy 0,2-0,5mm metodą iniekcji ciśnieniowej. Przykładowy pomiar szerokości rozwarcia rys przedstawia fot. 10 [2]. 


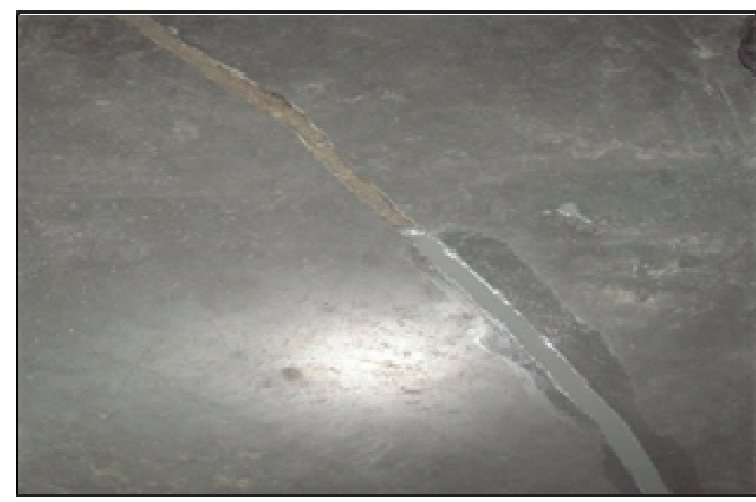

Fot. 9. Rysa wypełniana grawitacyjnie

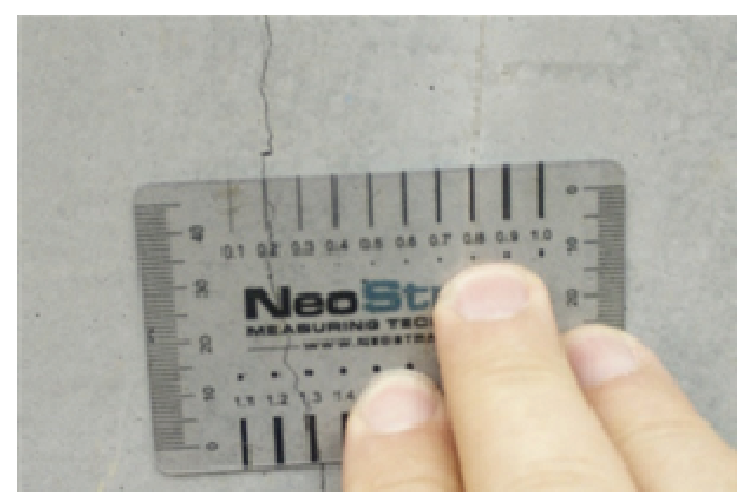

Fot. 10. Pomiar szerokości rysy

\section{Wnioski}

Projektowanie, a następnie realizacja obiektów spełniających funkcję garaży podziemnych jako obiektów wielkopowierzchniowych najczęściej jest związane z poważnymi problemami inżynierskimi. Obiekty o takim przeznaczeniu, powinny być tak zaprojektowane i wykonane aby były zgodnie $\mathrm{z}$ obowiązującymi aktami prawnymi $\mathrm{i}$ normami oraz $\mathrm{z}$ zasadami wiedzy technicznej. Podstawowym kryterium jakie musi zostać zrealizowane to, spełnienie wymagań podstawowych dotyczących wielkopowierzchniowych obiektów budowlanych tj. - warunki techniczne wykonania i odbioru robót budowlanych. Rozważając przywołane rodzaje wad i uszkodzeń, nasuwa się wniosek, że czynnikiem najbardziej inwazyjnym jest woda pochodząca $\mathrm{z}$ opadów atmosferycznych, nawieziona przez samochody jak i woda gruntowa oddziaływująca na część głęboko posadowioną konstrukcję.

Z tej też przyczyny, w garażach podziemnych do najczęściej spotykanych usterek zalicza się wady projektowo-wykonawcze ujawniające się wokresie eksploatacji obiektu. Dotyczy to niewystarczającej ilości zbrojenia lub jego złe rozmieszczenie, nie uwzględnienie w obliczeniach skurczu betonu prowadzi często do występowania w garażach usterek w postaci pęknięć płyty dennej oraz stropów pośrednich wynikających z błędnie przyjętych dylatacji lub błędnie rozpoznanych warunków gruntowo-wodnych [2,3].

Kolejną komplikacją jest przenikanie wód opadowych i gruntowych do garażu spowodowane zastosowaniem nieodpowiedniej izolacji. Aby zredukować powstawanie tego rodzaju wad rekomenduje się stosowanie gotowych rozwiązań systemowych opartych na sprawdzonych technologiach. Należy także ściśle przestrzegać i koordynowanie zastosowanych systemów na poszczególnych etapach wykonywanych prac, jak i szczegółowy odbioru robót. Należy również bezzwłocznie informowanie inwestora o wszelkich wadach i niezgodnościach występujących w projekcie przekazanym do realizacji inwestycji gwarantując zminimalizowanie wystąpienia usterek i prawidłową eksploatację garaży. 
1. Czarnecki L., Emmos, H. P. (2003). Naprawa i ochrona konstrukcji żelbetowych. Kraków : Polski Cement Sp. z o.o.,

2. Dohojda M., Szulc, J. (2015). Trwałe metody naprawcze w obiektach budowlanych. Budownictwo ogólne. W T. Błaszczyński, T. Buczkowski, W. Jaszczak i M. Kamiński (red.), Wrocław: Dolnośląskie Wydawnictwo Edukacyjne. (170-180).

3. Dohojda M., Wągrowska M., Witkowska-Dobrev J. (2017). Wielostanowiskowe garaże podziemne - przykłady rozwiązań konstrukcyjnych. Acta Sci. Pol. Architectura 16 (4), 27-35

4. Francke, B. (2010). Niewłaściwe rozwiązania hydroizolacyjne w garażach podziemnych. Materiaty budowlane, 3, 2-5.

5. Gradkowski, K. (2009). Wielopoziomowe budowle parkingów w dużych miastach. Przegląd komunikacyjny, 48(4), 41-47.

6. Kaliuszuk-Wietecka, A. (2010). Nieszczelne garaże. Przykłady nieszczelnych garaży, Materiaty Budowlane,3, 26 - 27.

7. Michalak, H. (2009). Garaże wilostanowiskowe. Projektowanie i realizacja. Warszawa : Wydawnictwo Arkady.

8. Michalak, H. (2009). Projektowanie i realizacja wielokondygnacyjnych garaży podziemnych. Budownictwo Podziemne,3, 32-39.

9. Potrzebowski, J. (2006). Parkingi i garaże cz. II Trwałość obiektu i bezawaryjna eksploatacja. Bilder, 7/8, 72-74.

10. Rokiel, M. (2013). Uszczelnianie dylatacji. Inżynier budownictwa. Pobrano z lokalizacji:

11. Rozporządzenie Ministra Infrastruktury z dnia 12 kwietnia 2002r. W sprawie warunków technicznych, jakim powinny odpowiadać budynki i ich usytuowanie (Dz. U. 2002 nr 75 poz. 690 , z późn. zm.)

12. PN-EN 1990:2004. Eurokod - Podstawy projektowania konstrukcji.

13. PN-EN 206:2014-04. Beton - Wymagania, właściwości, produkcja i zgodność.

14. PN-EN 1992-1-1:2008. Eurokod 2 - Projektowanie konstrukcji z betonu -Część 